\title{
Redescription of Anthrenus (s. str.) flavidulus Reitter, 1889, and a new synonym in Palaearctic Anthrenus Geoffroy, 1762 (Coleoptera: Dermestidae)
}

\author{
Marcin Kadej* \& Andreas Herrmann
}

Kadej, M. \& Herrmann, A. 2011: Redescription of Anthrenus (s. str.) flavidulus Reitter, 1889, and a new synonym in Palaearctic Anthrenus Geoffroy, 1762 (Coleoptera: Dermestidae). — Entomol. Fennica 22: 39-44.

The comparison of the morphology of the dorsal patterns, aedeagus, sternite IX and mouthparts of Anthrenus (s. str.) miniatulus Reitter, 1899 and Anthrenus (s. str.) flavidulus Reitter, 1889 proved that they belong to the same species. A photo of each adult form and male genitalia is provided. The name Anthrenus miniatulus Reitter, 1899 is proposed to become a junior synonym of Anthrenus flavidulus Reitter, 1889. Since Anthrenus miniatulus have also been found in Syria, the country name is now added to the distribution list of Anthrenus flavidulus.

M. Kadej, Department of Biodiversity and Evolutionary Taxonomy, University of Wrocław, ul. Przybyszewskiego 63/77, PL-51-148 Wrocław, Poland; *Corresponding author,e-mail:entomol@biol.uni.wroc.pl

A. Herrmann, Bremervörder Strasse 123, D-21682 Stade, Germany; E-mail: herrmann@coleopterologie.de; http://www.dermestidae.com

Received 5 November 2010, accepted 28 December 2010

\section{Introduction}

The genus Anthrenus is one of the commonly known genera of the beetle family Dermestidae and currently contains more than 200 species and subspecies worldwide; about a third of the species belongs to the nominative subgenus Anthrenus (s. str.) (Háva 2010).

Since the members of this subgenus often look extremely similar to each other, and furthermore, show a wide range of variation in colour, the examination of their genitalia and dissection of their mouthparts (especially lacinia and galea) provides a reliable method of identifying them down to species level.

\section{Material and methods}

The following abbreviations are used in the text:

- IZDBET - Institute of Zoology, Department of Biodiversity and Evolutionary Taxonomy, Wrocław, Poland.

- HMNH - Hungarian Natural History Museum, Budapest, Hungary.

- MiIZ-Zoological Museum, Academy of Sciences, Warszawa, Poland.

- RK - Roman KRÓLIK, Private collection, Kluczbork, Poland.

- ZIN - Zoological Museum, Academy of Sciences, St.-Petersburg, Russia.

- ZMAN - Zoologisch Museum, Amsterdam, Netherlands. 

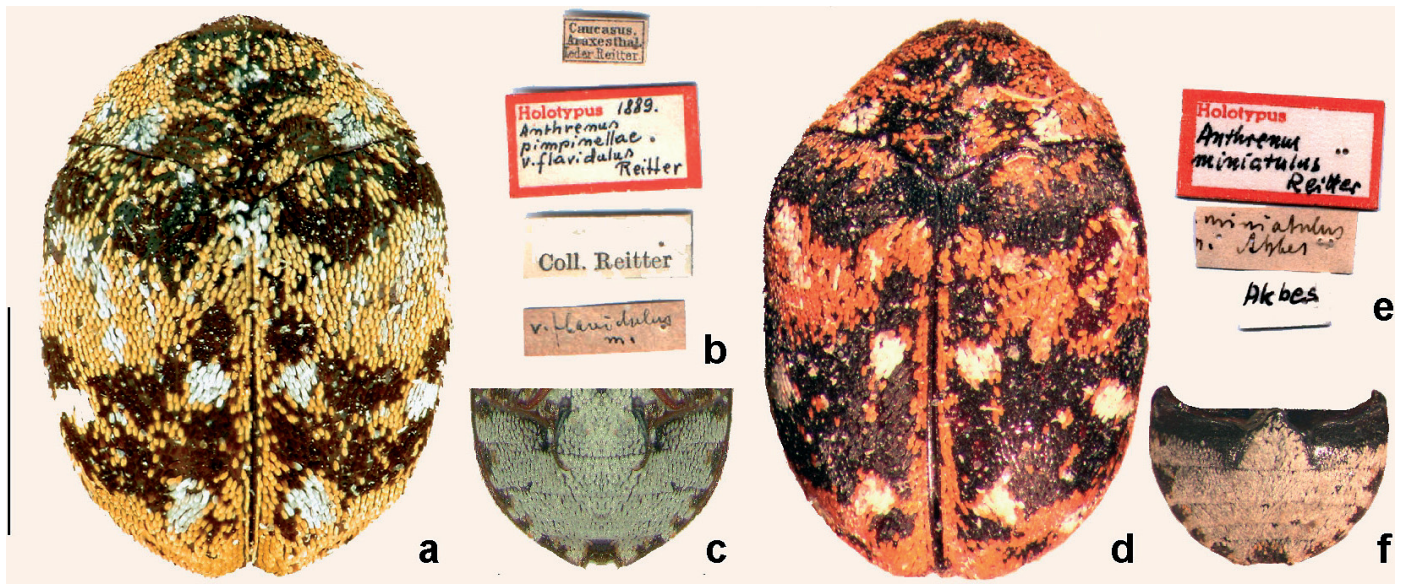

Fig. 1. Anthrenus (Anthrenus) flavidulus: - a. Habitus, dorsal aspect (holotype, photo after Zoltán György). - b. Labels of the holotype (photo after Zoltán György). - c. Abdominal ventrites I-V. Anthrenus (Anthrenus) miniatulus syn. n.: - d. Habitus, dorsal aspect (holotype). - e. Labels of the holotype (photo after Zoltán György). - f. Abdominal ventrites I-V.

The following abbreviations of measurements were used:

- total length (TL) - linear distance from anterior margin of pronotum to apex of elytra.

- total width (EW) - maximum linear transverse distance.

- pronotal length (PL) - maximum length measured from anterior margin to posterior margin.

- pronotal width $(\mathrm{PW})$ - maximum linear transverse distance.

- sternite length (SL) - linear distance from anterior margin of visible sternites $1-5$ to apex of sternite 5 .

- sternite width (SW) - maximum linear transverse distance.

The morphological structures were cleared in boiling $10 \% \mathrm{KOH}$ solution, rinsed in distilled water, mounted in glycerin and exposed to transmitted light, then examined, measured and illustrated under a Nikon Eclipse E 600 phase contrast microscope with a drawing tube attached. External structures were examined under Nikon SMZ-800 stereoscopic microscope. The aedeagus and associated structures were placed in glycerol filled plastic micro vials and attached to the pin of the corresponding specimen. Photos were taken with Nikon Coolpix 4500.

The distribution and classification follows the world catalogue of Háva $(2007,2010)$. The terminology follows Beal (1998) and Lawrence \& Ślipiński (2010).

Separate labels are indicated by a slash ( / ). Author's remarks are in square brackets [ ].

\section{Taxonomy}

Megatominae Leach, 1815

Anthrenini Casey, 1900

Anthrenus Geoffroy, 1762

Anthrenus flavidulus Reitter, 1889 (Figs. 1a-f, $2 \mathrm{a}-\mathrm{b}, 3 \mathrm{a}-\mathrm{d}, 4 \mathrm{a}-\mathrm{d})$

Syn.: Anthrenus miniatulus Reitter, 1899 syn. nov.

Type material examined. HNHM: Holotype: Caucasus. Araxesthal. Leder Reitter. / Holotypus 1889. Anthrenus pimpinellae v. flavidulus Reitter [label with the red frame; the date and the species name hand written] / Coll. Reitter / v. flavidulus m. [hand written]; Paratypus: Caucasus. Araxesthal. Leder Reitter. / Paratypus 1889. Anthrenus pimpinellae $v$. flavidulus Reitter [label with the red frame; the date and the species name hand written] / Coll. Reitter (Fig. 1a); Holotypus Anthrenus miniatulus Reitter [label with the red frame; the date and the species name hand written] / miniatulus m. Akbes [hand written] / Akbes (Fig. 1e). 


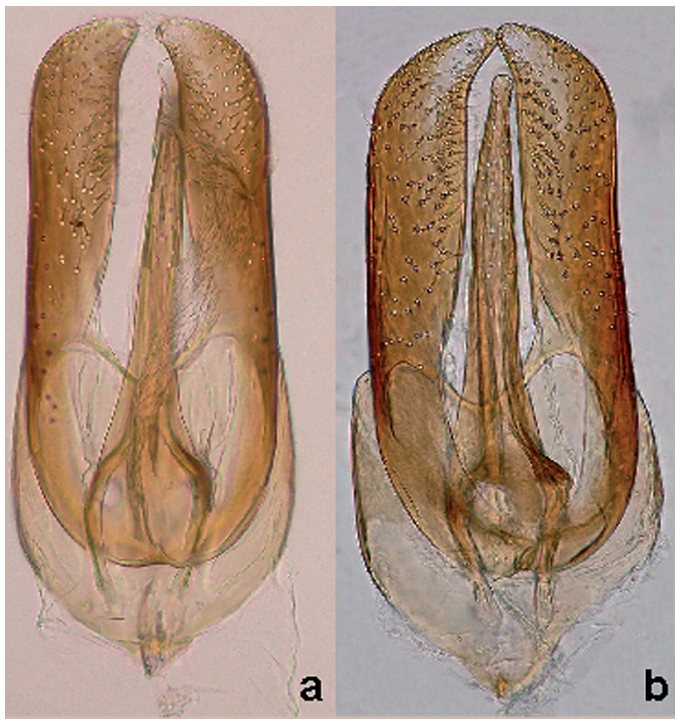

Fig. 2. - a. Aedeagus of Anthrenus (Anthrenus) flavidulus. - b. Aedeagus of Anthrenus (Anthrenus) miniatulus syn. $\mathrm{n}$.

Other material examined. MiIZ: Dzulfa, Cauc. merid., 31.V.1914, Dr. W. Eichler (1 ex.); ZMAN: Dzulfa, Cauc. Merid. 31.V.1914, Dr. W. Eichler (4 ехx.); ZIN: Тавризъ , Персіа 5 V 1914 Андріевский [leg.] (12 exx.); RK: Turkey (prov. Adiyaman) $37^{\circ} 54^{\prime} \mathrm{N} / 38^{\circ} 48^{\prime} \mathrm{E}$ S of Karadut vill. 3-4.VI.2002, Roman Królik leg. (1 ex.); Turkey $38^{\circ} 56^{\prime} \mathrm{N} / 41^{\circ} 09^{\prime} \mathrm{E}$ Buğlan Geçidi, $10 \mathrm{~km} \mathrm{E}$ of Solhan, prov. Muş., 10-12.VI.2004 h = 1,800 m, Roman Królik leg. (1 ex.).

Diagnosis. Anthrenus flavidulus Reitter, 1889 belongs to pimpinellae group together with 18 other species (Kadej et al. 2007). The main differentiator of pimpinellae group is found on the elytrae, especially, in a variation in colourful spots placement on the band: generally, in pimpinellae species group the transversal band consists of only white scales, while in A. flavidulus, the band has a diagonal pattern of red (sometimes yellow) scales.

A. flavidulus Reitter, 1889 (Armenia, Turkey, "Caucasus", Iran, Jordania after Háva 2010) at first glance resembles cosmopolitan A. p. pimpinellae (Fabricius, 1775). Beyond the transversal band, these species differ also in structure of aedeagus: in $A$. p p pimpinellae apical parts of parameres and base of aedeagus are narrow, while in A. flavidulus they are wide; setae on

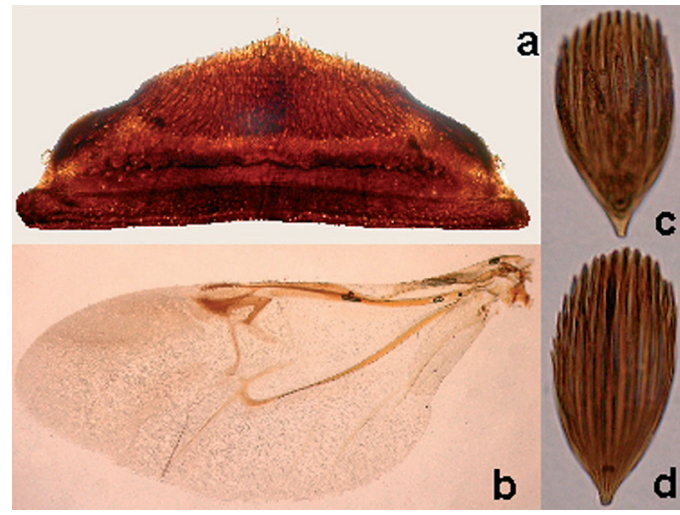

Fig. 3. Anthrenus (Anthrenus) flavidulus. - a. Pygidium. - b. Wing. - c-d. Scales.

parameres are longer and denser in $A$. p. pimpinellae, whereas they are short and sparse in $A$. flavidulus (Kadej et al. 2007).

Description of male. Body oval, with body length not exceeding 1.5 times maximum body width, covered by oval scales arranged in a colourful pattern on crest (Fig. 1a, d). Scales without ornamentation between linear ribs, their surface mostly with 12-14 complete linear ribs, apex of the scale truncated or rounded and an apical lappet not present (Figs. 3c-d). Head characterized by large convex eyes. Eye with median margin broadly and deeply emarginated at anterior $1 / 3$. Space of frons covered with reddish (yellowish) and brown scales. Pronotum two times broader than its length; lateral margins distinctly dilated above antennal fossa and slightly visible from above. Length of antennal fossa almost $1 / 2$ length of lateral margin of pronotum. Disc of pronotum covered with mixed dark brown, red (yellowish) and white scales (Figs. 1a, d). Antennae 11-segmented, with 3-segmented antennal club (Fig. 4a); antennal segments dark-brown. Antenna occupies whole cavity of antennal fossa. Antennal club occupies less than half length of the antenna regardless of sex. The last antennal segment rounded, and distinctly longer than length of two basal segments combined (Fig. 4a). Elytra covered with mixed dark brown, red (yellowish) and white scales (Figs. 1a, d). Subbasal band of red scales extends across elytra, between the red scales 3-4 oblique spots of white scales present. The band much shorter at suture than at lateral margin, middle margins of subbasal band 

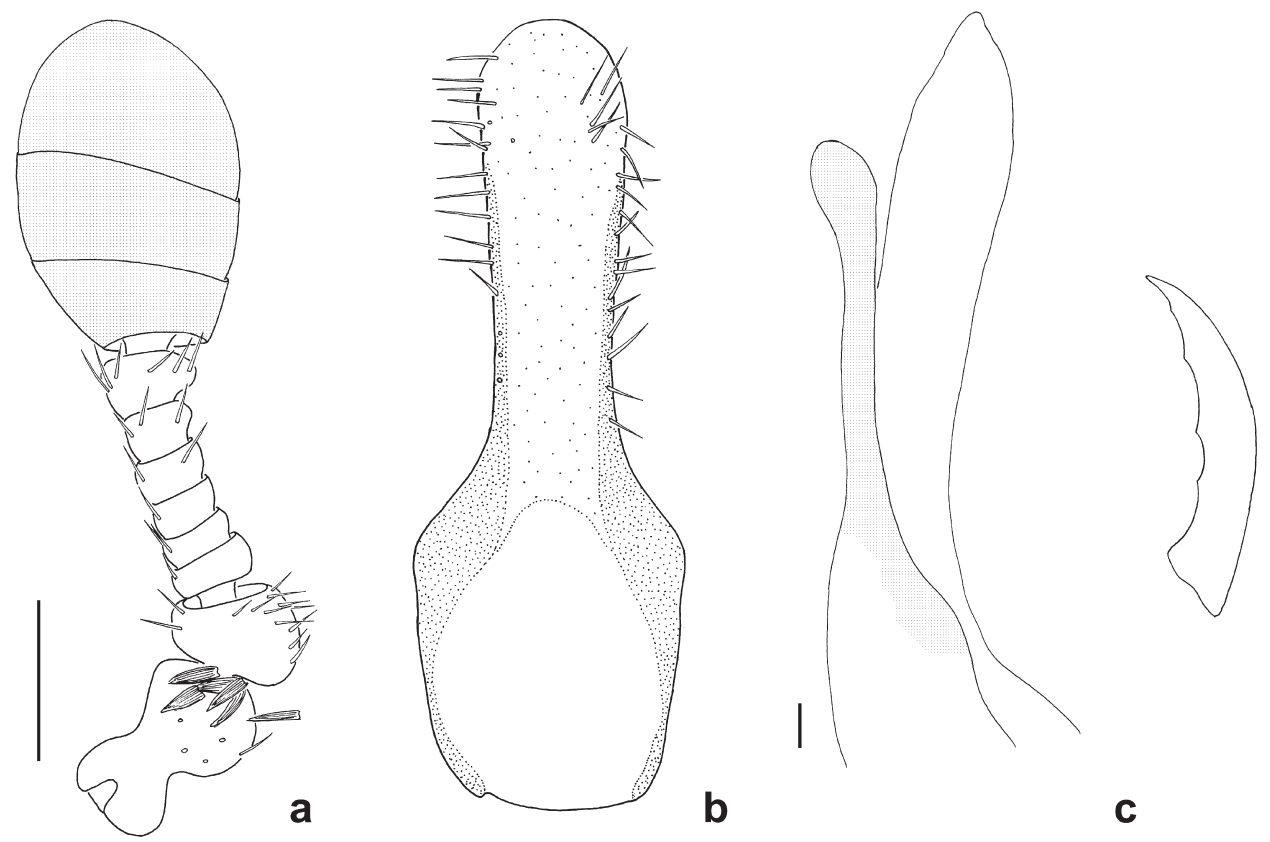

Fig. 4. Anthrenus (Anthrenus) flavidulus. - a. Male antenna (scale $0.1 \mathrm{~mm}$ ). - b. Sternite IX (scale 0.1 $\mathrm{mm}$ ). - c. Galea with lacinia (scale $0.01 \mathrm{~mm}$ ). - d. Tarsal claw (scale $0.01 \mathrm{~mm}$ ).

resemble an inverted letter U. Suture with line of red scales extending from behind of subbasal band or at least from middle lateral margin. Red patches also present near humeri, in the central part of disc, close to suture, and in basal third, near the lateral margin. The remaining areas between bands covered with dark brown scales mixed with single white scales, some of the white scales create 4 spots in the lower half of the elytra. Humeral calli present but barely distinguishable. Ventral surface with all scales white except for legs, and visible ventrites I-V covered with mix of brown, black and white scales. First abdominal ventrite has stria. Dark brown and brown scales present especially on femora, and anterolateral parts of the ventrites $\mathrm{I}-\mathrm{V}$, and in the center of ventrite $\mathrm{V}$ (Figs. 1c, f). The light brown scales around the dark brown spots on the ventrites. Tarsal claws of third pair of legs with three small denticles on inner margin (Fig. 4d). Tibiae of first pair of legs without distinct teeth (tibial spines) on lateral margin. Wing as in figure $3 \mathrm{~b}$. Pygidium with sub-basal, transverse, dark, carina-like line (Fig. 3a). Aedeagus small as in Fig. 2a-b. Parameres (basal lobes) U-shaped, with rounded apex, and slightly curved ventral. Parameres nar- row at base but gradually widen, covered with few short setae on lateral margins as well as in central and inner areas. Basal connection between lateral lobes is narrow and interrupted. Bridge (lightly sclerotized ribbon) narrow, Vshaped, close to the base of penis (Figs. 2a-b). Penis with visible sclerotized rode; in lateral view straight, with a distal end of aedeagus pointing up; in frontal view, wider posteriorly, with long and narrow apodemes which occupy $1 / 3$ of median lobe's length. Sternite IX bottle-like, narrow on top, wide at base, with a choke-point in middle. Apex slightly rounded. Setae present on top and lateral margins, but only in anterior part, extending only to half of total segment length. Lateral margins of sternite IX as well as its upper half have more pigment and are more sclerotized (Fig. 4b). Lacinia's length exceeds " of galea's length; ratio of lacinia's length to galea's length 4:5. Setae on apex of galea ended sharply (like spicisetae). Top of lacinia slightly curved, ventral, with sclerotized, bubble-like enlargement at end (Fig. 4c).

Observed variations. Body measurements varying from (mm): TL: 2.0-3.15, TW: 1.45-2.2, PL: 0.65-0.9, PW: $1.25-1.85$, SL: $1.05-1.45$ and 
SW: 1.5-2.1. Dorsal patterns vary in colour from red to yellow, which is common for many species of Anthrenus. Colour variations are often observed in A. scrophulariae, for example: one specimen might have red scales near the suture, while another might have yellow ones. The colour of scales might have also been affected by the age and storage conditions of the material.

Distribution. EU: Armenia, Turkey; AS: "Caucasus", Iran, Jordania, Syria (new record) (Reitter 1891, 1906, Dalla Torre 1911, Winkler 1926, Mroczkowski 1968, Kadej \& Háva 2007, Háva 2007, 2010).

\section{Discussion}

Anthrenus flavidulus was described by Reitter in 1889 as a colour variation of $A$. pimpinellae. In his description, colour forms were compared with A. delicatus delicatus Kiesenwetter, 1851 and $A$. cinnamomeus Gredler, 1878 (= Anthrenus flavipes flavipes LeConte, 1854). This taxonomical status was sustained in literature for years to follow. Zaitzev (1919) classified the taxon as endemic to "Caucasus". Finally, Zhantiev (1976) classified A. flavidulus as a separate species. Currently, Anthrenus flavidulus together with 18 other species is included in pimpinellae-group (Kadej et al. 2007). Anthrenus miniatulus was described 10 years later. In the original description, Reitter (1899) stated that it is very similar to Anthrenus fasciatus Reitter, 1881 (= Anthrenus flavipes flavipes LeConte, 1854) and Anthrenus fasciatus var. isabellae Reitter, 1899 (= Anthrenus flavipes albopunctatus Pic, 1895). It is surprising that the new species was compared to var. isabellae instead of previously described Anthrenus flavidulus (Reitter 1889) since both taxa are morphologically indistinguishable, as the above analysis proved. Therefore, A. miniatulus has been classified as a junior synonym of $A$. flavidulus.

Acknowledgements. We would like to express our sincere thanks to Michael Geisthardt and Mieczysław Stachowiak for valuable comments on the earlier version of this paper, Otto Merkl (HMNH) for lending the material of interest, and Zoltán György (HMNH) for providing some additional photographs. This work was supported by funding (1018/IZ/2011) from the Institute of Zoology, University of Wroclaw, Poland (IZDBET).

\section{References}

Beal, R. S. 1998: Taxonomy and Biology of Nearctic Species of Anthrenus (Coleoptera: Dermestidae). Transactions of the American Entomological Society 124: 271-332.

Casey, T. L. 1900: Review of the American Corylophidae, Cryptophagidae, Tritomidae and Dermestidae with other studies. - Journal New York Entomological Society 8 : 51-172.

Dalla Torre, K. W. 1911: Coleopterorum Catalogus. Pars 33: Nosodendridae, Byrrhidae, Dermestidae. - In: Junk, W. \& Schenkling, S. (eds.), Coleopterorum Catalogus. Berlin: W. Junk, 96 pp.

Geoffroy, E. L. 1762: Histoire abrégée des Insectes qui se trouvent aux environs de Paris, dans laquelle ces animaux sont rangés suivant un ordre méthodique. 1. Durand, Paris. xxviii +523 pp. +10 pl.

Gredler, V. P. 1878: Zur Käfer-Fauna Central-Afrikas. Verhandlungen der Kaiserlich-Königlichen Zoologisch-Botanischen Gesellschaft in Wien 27 (1877): 501-522.

Háva, J. 2007: Dermestidae. — In: Löbl, I. \& Smetana, A. (eds.), Catalogue of Palaearctic Coleoptera. Volume 4. Elateroidea, Derodontoidea, Bostrichoidea, Lymexyloidea, Cleroidea and Cucujoidea: 57, 299-320. Apollo Books Stenstrup. 935 pp.

Háva, J. 2010: Dermestidae of the World (Coleoptera). [www document]. URL http://www.dermestidae. wz.cz (Site visited on18 January, 2010)

Kadej, M. \& Háva, J. 2007: Contribution to the Dermestidae (Coleoptera) from Turkey. - Annals of the Upper Silesian Museum (Entomology) 14-15: 67-80.

Kadej, M., Háva, J. \& Kalík, V. 2007: Review of the Anthrenus pimpinellae species group from Palaearctic region (Coleoptera: Dermestidae: Anthrenini). — Genus 18: 721-750.

Kiesenwetter, E. A. H. 1851: Énumération des Coléoptères trouvés dans le midi de la France et en Catalogne. (Iie Partie 1). - Annales de la Societé Entomologique de France 9: 577-656.

Lawrence, J. F. \& Ślipiński, A. 2010: 6.1. Dermestidae Latreille, 1804. — In: Leschen, R. A. B., Beutel, R. G. \& Lawrence, J. F. (volume eds.), Coleoptera, beetles. Volume 2: Morphology and systematics (Elateroidea, Bostrichiformia, Cucujiformia partim): 198-206. In: Kristensen, N. P. \& Beutel, R. G. (eds.), Handbook of zoology. A natural history of the phyla of the animal kingdom. Volume IV. Arthropoda: Insecta. Part 38. Walter de Gruyter, Berlin, New York.

Leach, W. E. 1815: Entomology. — In: Brewster, D. (ed.): The Edinburgh Encyclopedia: 57-172. Vol. IX, part 1. Balfour, Edinburgh.

LeConte, J. L. 1854: Synopsis of the Dermestidae of the United States. - Proceedings of the Academy of the Natural Sciences of Philadelphia 7: 106-113.

Mroczkowski, M. 1968: Distribution of the Dermestidae (Coleoptera) of the world with a catalogue of all known species. - Annales Zoologici 26: 15-191. 
Pic, M. 1895: Descriptions d'especes et variétés de Coléoptčres asiatiques. - L'Échange, Revue Linnéenne 11: 142-144.

Reitter, E.1881: Bestimmungs-Tabellen der europäischen Coleopteren. III Heft. I. Auflage. Enthaltend die Familien: Scaphidiidae, Lathridiidae und Dermestidae. Verhandlungen der Kaiserlich-Königlichen Zoologisch-Botanischen Gesellschaft in Wien 30: 41-94.

Reitter, E. 1889: Neue Coleopteren aus Europa, den angrenzenden Ländern und Sibirien, mit Bemerkungen über bekannte Arten. Sechster Theil. - Deutsche Entomologische Zeitschrift 1889: 17-44.

Reitter, E. 1891: Dermestidae. — In: Heyden, L. von, Reitter, E. \& Weise, J.: Catalogus Coleopterorum Europeae, Caucasi et Armeniae Rossicae. Friedländer \& Sohn, Berlin. viii +420 pp.

Reitter, E. 1899: Ueber einige Coleopteren aus der palaearctischen Fauna und aus Japan. - Entomologische Nachrichten Berlin 25: 216-220.
Reitter, E. 1906: Dermestidae. — In: Catalogus Coleopterorum Europeae, Caucasi et Armeniae Rossicae. Auctribus Dr. L. von. Heyden, E. Reitter et J. Weise cum aliis sociis coleopterologicis. Editio secunda. Berlin: R. Friedländer \& Sohn, Paskau: E. Reitter, Caen: Revue d'Entomologie, vi +775 columns.

Winkler, A. 1926: Pars. 6. Dermestidae pp. 675-682; Thorictidae pp. 734-736. - In: Catalogus Coleopterorum Regionis Palaearcticae. Wien: A. Winkler, 19241932, 1698 pp.

Zaitzev, F. A. 1919: Materialy k faune zhestkokrylych Kavkazskovo kraya. VIII. Dermestidae et Bostrychidae. - Izvestiya Kavkazskogo Muzeya, Tiflis 12: 161-186.

Zhantiev, R. D. 1976: Zhuki kozheedy fauny SSSR. [The skin eaters family Dermestidae of fauna of the USSR.] Moskva. - Izdatelstvo Moskovskogo Universiteta, 180 pp. [In Russian.] 